\title{
A szellemi fogyatékosok fogászati- szájsebészeti ellátásának múltja, jelene és remélt jövője Magyarországon
}

\author{
Szmirnova Ilona dr. ${ }^{1}$ - Gellérd Emese dr. ${ }^{2}$ - Pintér Gábor Tamás dr. ${ }^{1}$ \\ Szmirnov György dr. ${ }^{1}$ - Németh Zsolt dr. - Szabó György dr. ${ }^{1}$
}

\author{
'Semmelweis Egyetem, Fogorvostudományi Kar, Arc-, Állcsont-, Szájsebészeti és Fogászati Klinika, Budapest \\ ${ }^{2}$ Semmelweis Egyetem, Általános Orvostudományi Kar, Aneszteziológiai és Intenzív Terápiás Klinika, Budapest
}

Bevezetés: A szellemi fogyatékosok fogászati ellátása egyre nagyobb kihívások elé állítja az egészségügyet. Magyarországon mintegy 100000 olyan értelmi fogyatékos van, akik speciális ellátásra szorulnak.

Célkitüzés: Retrospektív vizsgálatunk célja, hogy nemzetközi összehasonlításban összefoglaljuk a Semmelweis Egyetem (SE) Arc-, Állcsont-, Szájsebészeti és Fogászati Klinikájának Rehabilitációs Osztályán az utóbbi 5 évben ellátott szellemi fogyatékos betegek demográfiai adatait, a beteganyag összetételét és a terápiás eredményeket.

Módszer: A súlyos értelmi fogyatékosok fogászati ellátása csak altatásban lehetséges. A SE Arc-, Állcsont-, Szájsebészeti és Fogászati Klinikáján az utóbbi 5 évben 1717 felnőtt értelmi fogyatékos beteget kezeltek altatásban. (Enyhe, közepes, súlyos értelmi fogyatékosokat, Down-kórosakat, autistákat, epilepsziás és pánikbetegeket.)

Eredmények: A legfontosabb eredmény, hogy úgy túnik, az akut fogászati, szájsebészeti ellátás csaknem megoldott. Az ezeket a betegeket segítő alapítványokkal, szervezetekkel jó kapcsolatrendszer alakult ki. Megmutatkozott viszont az az óriási szükséglet, amely az értelmi fogyatékos betegek prevenciójával, gondozásával kapcsolatos.

Következtetés: Magyarországon még nem született olyan felmérés, amely ezeknek a betegeknek a fogászati ellátási szükségleteit objektíve felmérte volna. Nemzetközi viszonylatban viszont több ilyen közlemény ismert. Ezek alapján megállapítható, hogy mind a cariesfrekvencia, mind a parodontalis betegségek előfordulása növekszik a korral és a retardáltság mértékével. A szájhigiéné nem kielégítő, a betegek, illetve gondozóik nem kapnak kielégítő információt, csak nagyon kevesen vesznek részt megfelelő képzésben, nem motiváltak a szájüregi egészség megőrzésében. A fogászati ellátás - az akut esetek kivételével - nem kielégítő. A kezelésben a prevenció érdekében szorosan együtt kell múködni az erre szakosodott civil szervezetekkel, alapítványokkal, gyógypedagógusokkal, pszichiáterekkel. Orv Hetil. 2019; 160(35): 1380-1386.

Kulcsszavak: szellemi fogyatékosok, fogászati kezelés, narkózis

\section{Dental and oral surgical treatment of the mentally retarded in Hungary: the situation in the past, currently and hopes for the future}

Introduction: Dental care for mentally disabled people poses a growing challenge for healthcare. In Hungary, the number of mentally disabled people needing special dental care is $c a .100000$.

Aim: The aim of our retrospective analysis is to provide a summary of the demographic data and the treatment outcomes of patients with mental disorders treated at the Department of the Oral and Maxillofacial Surgery of the Semmelweis University in the past five years.

Method: Dental care for patients with a severe level of mental disability can be carried out in general anaesthesia only. At Semmelweis University, in the Oral and Maxillofacial Department, 1717 mentally disabled adults received dental care during the past five years. (Patients included people with a mild, medium or severe level of mental disability, patients with Down's syndrome, autism, epilepsy or panic disorder.)

Results: The single biggest achievement seems to be the fact that the issue of acute dental care and oral surgery has basically been settled. A workable relationship has been forged with foundations and organizations dealing with the problems of these patients. It has been realized, however, that in the case of mentally disabled patients there is an enormous need for prevention and ongoing care.

Conclusions: Up to now no survey has been carried out in Hungary with the aim of objectively revealing the dental care needs of these patients. Internationally, however, several surveys have been published. It can be stated on the 
basis of these that both caries frequency and the presence of parodontal diseases increase in correlation with age and the level of disability. Oral hygiene is insufficient, patients or their caretakers do not get proper information, only a few of them receive adequate training and they are not motivated to keep up oral health. Dental care, except for tending acute cases, is not satisfactory. For the sake of prevention, cooperation is needed with non-governmental organizations, foundations, special education teachers and psychiatrists specialized in this field.

Keywords: mentally disabled, dental treatment, narcosis

Szmirnova I, Gellérd E, Pintér GT, Szmirnov Gy, Németh Zs, Szabó Gy. [Dental and oral surgical treatment of the mentally retarded in Hungary: the situation in the past, currently and hopes for the future]. Orv Hetil. 2019; 160(35): 1380-1386.

(Beérkezett: 2019. március 8.; elfogadva: 2019. április 12.)

A szellemi fogyatékosok fogászati ellátása az új kihívások miatt az egészségügynek egyre sürgetőbb, komplex problémát jelent. Mik ezek az „új kihívások”? A fogyatékosok számának relatív növekedése, az egészségügyi ellátáshoz füződő emberi jogok fokozott figyelembevétele, a fogyatékosgondozás javulása és az annak következtében fokozódó igények.

A „Komplex fogorvosi program értelmileg fogyatékos és halmozottan sérült emberek számára" című tanulmány 14 résztvevő közremúködésével 23 éve, 1996-ban született meg [1]. Ebből idézünk néhány mondatot:

„Gyógypedagógusok, fogyatékos gyermekeket vagy fiatalokat tanító szakemberek az iskolában tanúi a fogászati problémák megoldatlanságának, a szülők és a gyermekek szenvedéseinek. Sem az iskolafogászatok, sem a gyermek-, illetve felnőtt fogászati rendelések nincsenek felkészülve az értelmi fogyatékosok ... betegek fogadására."

A program 3 pontban foglalta össze a tennivalókat:

1. prevenció;

2. ingyenes szürés és kezelés;

3. fogászati kezelés altatásban.

Az eltelt idő alatt sok minden jó irányban változott, de tennivaló akad még bőven.

Nem kívánunk részletesen foglalkozni a fogyatékossággal kapcsolatos magyar és nemzetközi definíciókkal; a többféle meghatározásból csak egyet emelnénk ki, melyet az Egyesült Nemzetek Szervezete (ENSZ) 2000ben a következőképpen definiált: „,...azt a személyt kell fogyatékosnak tekinteni, aki egy hosszabb távon jelentkező fizikai, szellemi vagy egyéb egészségügyi probléma miatt bizonyos fajta vagy bizonyos mennyiségű tevékenység elvégzésére alkalmatlan" [2].

$\mathrm{Az}$ Európai Unió 27 tagállamának népességszáma 2011-ben 503663601 fó volt, melyből minden hatodik ember, azaz 80 millió fogyatékossággal él, ezért az ENSZ ,a világ legnagyobb kisebbségének” nyilvánította ezt a csoportot (Képviselői Információs Szolgálat, 2013) [2].

A Központi Statisztikai Hivatal 2009-es adatai szerint [3] Magyarországon a tartósan betegek száma 1648413 volt, ezek közül 5120 autista, 42779 értelmi fogyatékos és 46265 mentálisan, pszichésen sérült egyén volt.
A tartósan betegek közül kb. 320000 szorul speciális fogászati ellátásra.

A legnehezebb problémát a súlyos értelmi fogyatékosok jelentik, akiket valóban csak altatásban lehet kezelni. $\mathrm{Az}$ enyhén vagy közepesen súlyos betegek egy részét megfelelő előkészítés után helyi érzéstelenítésben el lehet látni. A súlyos betegek akut fogászati ellátása az utóbbi 6-8 évben sokat javult. Az ország nagyvárosaiban vannak olyan centrumok, ahol altatásban a szájsebészeti és részben a parodontológiai kezelés többé-kevésbé megoldott. Sajnos a fogmegtartó eljárások ezeknél a betegeknél (fogtömés, pótlások) csak nagyon kevés esetben kivitelezhetők.

A szellemi fogyatékossággal élők fogászati ellátása, ennek a szükségletnek a felmérése és a különböző prevenciós eljárások ma már nemzetközileg aktuális problémát jelentenek. Több országban (Japán, Korea, Írország, Oroszország stb.) történtek felmérések a kezelendő betegek számáról, a terápiás megoldásokról és a megelőzéssel kapcsolatos lehetőségekről, illetve eredményekről [4-16].

\section{Célkitüzés}

Retrospektív vizsgálatunk célja, hogy nemzetközi összehasonlításban összefoglalja a Semmelweis Egyetem (SE) Arc-, Állcsont-, Szájsebészeti és Fogászati Klinikájának Rehabilitációs Osztályán az utóbbi 5 évben ellátott fogyatékos betegek demográfiai adatait, a beteganyag öszszetételét és a terápiás eredményeket.

\section{Betegek és módszer}

A SE Rehabilitációs Centrumának megnyitása óta, 2014. október 1-tôl 2018. december 31-ig, 1717 értelmi fogyatékos beteget kezeltek altatásban.

A mútétek előtt előzetes vizsgálatot, állapotfelmérést csak akkor tudtak végezni, ha az nem járt külön altatással. Röntgenvizsgálat technikai okokból fóleg az enyhe és a középsúlyos értelmi fogyatékosoknál volt lehetséges. Az altatást megelőzte egy telefonos konzultáció az altatóorvos és a betegek gondozója között. Tekintettel arra, hogy a súlyos értelmi fogyatékosok nehezen mozgatha- 
tók, belgyógyászati, kardiológiai, neurológiai stb. vizsgálat csak abban az esetben volt szükséges, ha azt az altatóorvos a telefonos konzultáció alapján úgy ítélte meg.

Az intravénás altatást $2 \mathrm{mg}$ Dormicum (midazolám) plusz $0,5-1 \mathrm{mg} / \mathrm{ttkg}$ propofol, szükség esetén 20-30 mg propofol bolusszal folytatják. Orrszondán 2 liter/ perc oxigént kap a beteg. A beavatkozás végén $0,2 \mathrm{mg}$ Anexate-tal (flumazenil) függesztik fel a Dormicum-hatást.

Intubációs altatás esetén $2 \mathrm{mg}$ Dormicum, 50-100 mg fentanil, 1-1,5 mg propofol indukciója után 0,5 $\mathrm{mg} / \mathrm{ttkg}$ atrakuriumrelaxáció mellett intubálnak. A narkózist $50 \%$ oxigén, $50 \% \mathrm{~N}_{2} \mathrm{O}$ és Sevorane inhalációjával tartják fenn. A beavatkozás végén $0,2 \mathrm{mg}$ Anexate-tal függesztik fel a Dormicum hatását.

A beavatkozás, illetve az altatás után a betegeket a szükséges ideig a Rehabilitációs Osztály személyzete felügyelte. A betegek többségét rendszeres ellenőrzésre kérték vissza (3-6 hónap); amennyiben a személyes kontroll nehézségbe ütközött, az osztály vezetője a beteg gondozójával vette fel a kapcsolatot.

\section{Eredmények}

1) A legfontosabb eredmény, hogy az értelmi fogyatékosok akut fogászati, szájsebészeti ellátása tekintetében nagy lépést tettünk előre. Habár most csak a Semmelweis Egyetem Arc-, Állcsont-, Szájsebészeti és Fogászati Klinikájának a munkájáról van szó, úgy tűnik, hogy az országosan múködő 6 centrumban kevesebb beteggel, de hasonló eredményt értek el.

2) A betegek diagnózis szerinti megoszlása látható az 1. táblázatban. Az betegek döntő többsége az enyhe (125), közepes (695) és súlyos (326) értelmi fogyatékosok közül került ki. Autista 185, a Down-kóros betegek között megkülönböztetünk enyhe (101) és súlyos eseteket (32). Idesorolhatók az epilepsziás (166) és a pánikbetegek (43) is, mert ellátásuk éppúgy altatásban történt, mint az értelmi fogyatékosoké. $\mathrm{Az}$ ún. „más szindrómába" tartozó betegek között Asperger-szindrómás 36, Hallervorden-Spatz-szindrómás 1 , sclerosis tuberosás 2, fragilis X-szindrómás 1 , Beckwith-Wiedemann-szindrómás 1 , míg Williams-szindrómás 3 beteg volt. Minden betegségcsoportban feltüntettük a betegek nemét és az átlagéletkort. Az összesítésben 1115 férfi és 602 nő szerepelt, átlagéletkoruk 32,8 év volt.

3) A 2. táblázatban a beavatkozások milyenségét tüntetjük fel. Látható, hogy a legtöbb beavatkozás az extractio és a sebészi feltárás volt (4219, 1691 betegen). Ez érthető is, mivel akut mútétekről volt szó.

A fogtömések általában az akut mütétekkel egy időben vagy egy másik időpontban ugyanúgy altatásban történtek. Lehetőség szerint az összes szuvas fogat igyekeztek ilyenkor ellátni, így a 2616 tömést 1610 betegen végezték.
1. táblázat Értelmi fogyatékosok akut fogászati beavatkozásai altatásban 2014. október 1. és 2018. december 31. között

\begin{tabular}{|c|c|c|c|c|}
\hline Betegség & Betegszám & Férfi & Nő & Átlagéletkor \\
\hline Enyhe értelmi fogytékos & 125 & 84 & 41 & 30 \\
\hline $\begin{array}{l}\text { Közepesen értelmi } \\
\text { fogyatékos }\end{array}$ & 695 & 393 & 302 & 36 \\
\hline Súlyos értelmi fogyatékos & 326 & 284 & 42 & 28 \\
\hline Down-szindróma enyhe & 101 & 80 & 21 & 33 \\
\hline Down-szindróma súlyos & 32 & 18 & 14 & 27 \\
\hline Autista & 185 & 95 & 90 & 29 \\
\hline Asperger-szindróma & 36 & 22 & 14 & 29 \\
\hline $\begin{array}{l}\text { Hallervorden-Spatz- } \\
\text { szindróma }\end{array}$ & 1 & 1 & - & 31 \\
\hline Sclerosis tuberosa & 2 & 2 & - & 19 \\
\hline Fragilis X-szindróma & 1 & 1 & - & 21 \\
\hline Williams-szindróma & 3 & 3 & - & 25 \\
\hline $\begin{array}{l}\text { Beckwith-Wiedemann- } \\
\text { szindróma }\end{array}$ & 1 & - & 1 & 21 \\
\hline Epilepszia & 166 & 124 & 42 & 37 \\
\hline Pánikbeteg & 43 & 8 & 35 & 32 \\
\hline Összesen & 1717 & 1115 & 606 & 32,8 \\
\hline
\end{tabular}

2. táblázat Altatásban elvégzett beavatkozások értelmi fogyatékosok esetében 2014. október 1. és 2018. december 31. között

\begin{tabular}{lcc}
\hline Beavatkozás & A beavatkozások száma & Betegszám \\
\hline Fogtömés & 2616 & 1610 \\
Extractio, sculptio & 4219 & 1691 \\
Gyökértömés & 104 & 87 \\
Cystectomia & 12 & 12 \\
Depurálás & 1184 & 1184 \\
Biopszia & 12 & 12 \\
\hline Összesen & 8147 & 4596
\end{tabular}

A betegek legtöbbjének igen gondozatlan volt a fogazati állapota, ezért amikor csak lehetővé vált, az esetek többségében fogkö-eltávolitás is történt (1184 esetben).

Cystectomiát (10 radicularis, 2 follicularis cysta) 12 beteg esetében végeztek. A 12 biopszia eredménye: 10 gyulladásos elváltozás és 2 epulis (perifériás óriássejtes granuloma) volt.

A gyökértöméseket (104) 87 betegen a frontfogak esetében végezték, a beavatkozásokat főleg akut fogbélgyulladás indokolta.

4) A fogászati kezelések és az altatás során bekövetkezett szövődményeket a 3. és 4. táblázatban foglaltuk össze.

A sebészi múveletek alatt a leggyakoribb szövődmény a fogak, gyökerek törése volt (117). A mütétek során olyan 
3. táblázat |Altatásban végzett fogászati beavatkozások szövődményei

\begin{tabular}{lc}
\hline Fogászati beavatkozások szövődményei & Száma \\
\hline Fog- vagy gyökértörés & 117 \\
Posztoperatív vérzés & 12 \\
Alveolitis & 41 \\
Pulpitis & 47 \\
Helyi érzéstelenítés után ajak-bucca harapás & 8 \\
\hline Összesen & 225 \\
\hline
\end{tabular}

4. táblázat |Altatás közben bekövetkezett szövődmények

\begin{tabular}{lc}
\hline Az általános anesztézia szövődményei & Száma \\
\hline Deszaturáció & 5 \\
Hányinger, hányás & 80 \\
Agitáció & 18 \\
Hidegrázás & 11 \\
\hline Összesen & 114 \\
\hline
\end{tabular}

vérzés, amely varrattal nem volt megoldható, nem lépett fel. Posztoperatív vérzést a megfigyelési idő alatt 12 esetben észleltek, ezeket újabb altatás során sikerült ellátni. Mütét utáni gyulladás (alveolitis) 41 esetben volt. Ezek többsége antibiotikus kezelésre meggyógyult, csak 8 betegnél kellett újabb sebészi beavatkozást végezni (excochleatio vagy a gyökértömött fog extractiója). A 2616 fogtömés után 47 esetben jött létre pulpitis, mely miatt extractióra került sor.

Altatás közben 5 betegnél volt deszaturáció, 18 esetben agitáció. Altatás utáni hányást, hányingert 80 esetben észleltek. Hidegrázás 11 volt. Orvvérzés egy esetben sem volt, mivel az intratrachealis tubust nem az orron át vezették le.

\section{Megbeszélés}

Magyarországon több mint 100000 olyan értelmi fogyatékos él, akinek a fogászati kezelése csak altatásban történhet. Budapesten 4 év alatt csaknem 1800 beteg szorult akut ellátásra. Az irodalmi adatok az értelmi fogyatékosok kezelésével kapcsolatban fóleg az akut, altatásban végzett ellátásról számolnak be $[6,7]$. Vannak, akik az altatás alatt teljes rehabilitációra törekszenek (extractio, tömés, pótlás), de ez az altatás idejét meghosszabbítja, és a betegszámot csökkenti ( 10 év alatt 200 betegről számolnak be Solanki és mtsai) [9]. Az idevonatkozó közlemények [17, 18] hangsúlyozzák a fokozott rizikófaktort, hiszen fóleg a súlyosan retardált betegeknél a preoperatív kivizsgálás jóval nehezebb, komplikáltabb, mint a normálbetegek esetében. Többen $[6,7,17]$ hangsúlyozzák, hogy ezeket a betegeket a legrövidebb ideig szabad csak kiszakítani megszokott kör- nyezetükből. Így az általunk alkalmazott protokoll megfelel a nemzetközi elvárásoknak.

Érdekes összehasonlítást tenni az altatással kapcsolatos intra- és posztoperatív szövődmények tekintetében. Tajvani szerzők [7] 200 értelmi fogyatékos gyermek és felnőtt beteg intubációja után minden hatodik beteg esetében észleltek orrvérzést, minden harmadik esetben agitációt, ami az intravénás narkózis esetében kevesebb volt, viszont több deszaturációt, hányingert, hányást, hypothermiát észleltek az utóbbiaknál. A mi jóval több altatásos esetünkben orrvérzést nem észleltek (az intratrachealis tubust nem az orron át vezették le). Deszaturációt, hányást is csak néhány esetben észleltek.

Tajvani [7] és spanyol [18] szerzők hangsúlyozzák, hogy mind az intravénás, mind az intratrachealis narkózis esetében szükséges a fogorvos-szájsebész és az aneszteziológus állandó együttmúködése.

Maeda és mtsai [19] 106 felnőtt értelmi fogyatékos altatása során azt a következtetést vonták le, hogy az intravénás midazolám után hosszabb ébredési fázis következik, ezért ezt nem javasolják az ambulanter kezelt betegek esetében.

Sitkin és mtsai [20] 65 értelmi fogyatékos gyermeket (ASA 2-3.) szevofluránnal altattak. Azt tapasztalták, hogy mindegyik betegnél bizonyos idő múlva hypoventilatio lépett fel, de a túlsúlyos betegek esetében ez sokkal gyakrabban következett be.

Magyarországon 2014. október és 2018. december között az eddigi felmérések szerint kb. 3000 beteget kezeltek. Az általunk végzett kezelések során kitűnt, hogy a betegek 90\%-ának további fogmegtartó vagy/és protetikai kezelésre lenne szüksége, amit az akut ellátás során csak kis részben lehetett elvégezni (összesen 2616 tömés, pótlás egy sem). A magyarországi felmérések szerint [3] a normálpopuláció cariesfrekvenciája az európai országok többségéhez viszonyítva aránylag magas: 3,3 DMF-T; Hollandiáé például 0,8. (Az Egészségügyi Világszervezet [WHO] a cariologiai status értékelésére a DMF-T-számot használja a maradó fogakra vonatkoztatva, illetve dmf-t-t a tejfogak esetében [decayed - szuvas, missing - hiányzó, filled - tömött, tooth - fog]).

Ha ehhez a magas, 3,3 DMF-T-számhoz hasonlítjuk a szellemi fogyatékosok fogazati állapotát, sokkal rosszabb adatokat kapunk, kapnánk. Tudniillik magyar nyelvü tudományos folyóiratban a szellemi fogyatékosok fogazati állapotáról nem tudunk olyan felmérést, amely objektív adatokat tartalmazna (egy olyan magyar nyelvű közleményt ismerünk, amely a fogatlan epilepsziás betegek fogsorának implantátumokkal való rögzítéséról szól, egyet a prevencióval kapcsolatban és egy német közleményt magyarra fordítva, amely a fogyatékosok kezelésének általános elveiról szól) [21-23].

Nemzetközi viszonylatban viszont több olyan publikáció van, mely a mentálisan retardált és a normálegyének fogazati és ezzel kapcsolatos anatómiai képleteit, az állcsontok, a temporomandibularis ízület állapotát hasonlítja össze. 
Tanboga és mtsai [24] 64 értelmi fogyatékos és 105 hasonló korú egészséges fiatal temporomandibularis ízületi állapotát vetette össze. Megállapították, hogy az értelmi fogyatékosok esetében szignifikánsan több ízületi probléma volt regisztrálható, mint az egészséges egyéneknél.

Abeleira és mtsai [25] 40 Down-szindrómás beteg vizsgálata során a maradó fogak szignifikáns microdontiáját állapították meg.

McKinney és mtsai [26] Angliában 2772 autista (1517 éves) gyermek fogászati állapotát mérték fel. Megállapították, hogy több mint 15\%-ban nem jutottak megfelelő fogászati kezeléshez.

Chang és mtsai [16] 102 súlyos értelmi fogyatékos fogászati állapotát hasonlították össze 100 normálegyénével. Megállapították, hogy az előbbiek cariesfrekvenciája kétszer akkora volt, mint a normálegyéneké.

Solanki és mtsai [13] 200 értelmi fogyatékos gyermek teljes fogászati rehabilitációját végezték altatásban. Felméréseik szerint minél súlyosabb a pszichiátriai betegség, annál rosszabb a fogazati status.

Naouri és mtsai [27] 2222, Franciaországban, intézetben lévő, fogyatékos felnőtt orvosi és fogorvosi szükségleteit hasonlították össze a normálpopuláció hasonló igényeivel. Megállapították, hogy a jóval rosszabb fogazati helyzet ellenére ötször kevesebb lehetőségük van a megfelelő kezelés elérésére, mint az egészséges embereknek.

Chbajed és mtsai [14] 152, 5 és 15 év közötti, mentálisan retardált indiai gyermek fogazati statusát mérték fel. Az eredményeket összehasonlították a gyermekek szocioökonómiai helyzetével, az értelmi fogyatékosság milyenségével. Megállapították, hogy a dentalis status annál rosszabb, minél rosszabb a gyermekek szociális helyzete. Az autistáknak jobb fogaik voltak, mint a Down-szindrómásoknak.

Ismailov [15] 17l fogyatékos beteg vizsgálata alapján megállapította, hogy 18 és 25 éves korban 34\%-ban szenvednek parodontalis betegségekben. Ez a szám a 42 évnél idősebbeknél 82\%-ra növekszik.

Mac Giolla Phadraig és mtsai [28] Írországban egy ún. „Delphi panel” felmérésben azt a kérdést járták körül, hogy a fogorvosi ellátásnak mit kellene tennie az értelmi fogyatékosok érdekében. A felmérésben fogorvosi rendelők, értelmi fogyatékosok, illetve azok képviselői vettek részt. Az eredményben 16, konszenzusos megállapítást tettek, melyek az egyéni kezelési lehetőségekre, információáramlásra, tréningekre, költségekre stb. vonatkoztak. A legfontosabb megállapítások a kezelési lehetőségeket adó épületre, felszerelésre és a személyzetre vonatkoztak. A kezelés költségeit nagyrészt alapítványok biztosították, illetve biztosítanák.

$\mathrm{Az}$ értelmi fogyatékosok kezelése sokkal nehezebb, költségesebb, és az eredmények kevésbé látványosak, mint a normálegyéneké. Az egészségügyi ellátás kevésbé fókuszál ezekre a betegekre. Ezért van az Magyarországon, hogy - bár nagy az előrelépés - gyakorlatilag csak az akut ellátás megoldott (többé-kevésbé).
Különböző országokban látunk (lassú) előrehaladást. Javaslatokat tesznek, mint például Waldman és mtsai [29]: mindenekelőtt felmérésekkel kell országosan meghatározni az értelmi fogyatékosok fogászati ellátáshoz kapcsolódó szükségleteit. Ennek alapján olyan központokat kellene szervezni, ahol az általános orvosok, pszichiáterek mellett a fogászati ellátást is biztosítani lehet, beleértve a fogmegtartó kezelést és a prevenciót is. Ezenkívül a privát rendelőket is fel kell készíteni az értelmi fogyatékosok ellátására. Ez azért lenne fontos, mert míg az 1960-as években az Egyesült Államokban negyedmillió értelmi fogyatékos élt intézetekben, 30 év múlva, az egészségügyi politika változásával, több mint 75\%-uk családi otthonokban, szétszórva lett elhelyezve. Így fogászati ellátásuk bizonyos fokig megnehezült, mert a kisebb közösségek erre nincsenek felkészülve.

Világszerte, nem csak Magyarországon, jóval több a nem csak akut ellátásra szorulók száma, mint az erre igénybe vehető kapacitás (hely, orvosok, pénzügyi feltételek). Éppen ezért előtérbe kell, hogy kerüljön a megelőzés. A megelőzésre több módszert írtak le, talán az egyik leglátványosabb eredményről Edwards és mtsai [10] számoltak be már 2002-ben. Merseyside megyében (Liverpool környéke Középnyugat-Angliában), ahol az értelmi fogyatékosok szétszórtan élnek, a fogorvosok között pályázatot hirdettek a mentálisan retardált egyének kezelésére. A betegek és hozzátartozóik körében tanuló-, tréningprogramokat szerveztek, hogyan segítsék elő a szájápolást. Az orvosok külön anyagi segítséget vehettek igénybe, a betegek és hozzátartozóik folyamatos, ellenőrzött programokon vehettek részt. Ez a program néhány év alatt jelentôsen csökkentette az akut ellátásra szorulók körét, és lényeges javulást hozott a betegek fogászati állapotában.

Más szerzők [11, 30] naponta klórhexidin spray-vel vagy triklozán-cink oldattal öblítették a betegek száját, ami visszaszorította az állandóan jelen levő gingivitist. 2-8 hét alatt látványos eredményt értek el.

A következőkben, egy második közleményben, azt szeretnénk bemutatni, hogyan lehet objektív felmérést készíteni Magyarországon az értelmi fogyatékosok fogazati, szájüregi állapotáról, a kezelések szükségességéról.

A prevencióval kapcsolatosan tréningprogramokat tervezünk indítani. Külön hangsúlyozni kívánjuk az értelmi fogyatékosokkal foglalkozó különböző szervezetekkel (Down Alapítvány, autistaszervezetek, Értelmi Fogyatékossággal Élők és Segítőik Országos Érdekvédelmi Szövetsége - ÉFOÉSZ) való szoros kapcsolatot.

\section{Következtetés}

A nemzetközi tapasztalatokat és a sajátjainkat összefoglalva megállapíthatjuk a következőket:

- Mind a cariesfrekvencia, mind a parodontalis betegségek előfordulása növekszik a korral és a retardáltság mértékével. 
- A szájhigiéné nem kielégítő a retardált szint szerint felosztott egyik csoportban sem.

- A mentálisan sérültek, illetve gondozóik nem kapnak kielégítő információt, nem vesznek részt, vagy csak nagyon kevesen megfelelő képzésben, nem motiváltak a szájüregi egészség megőrzésében.

- A fogászati ellátás - az akut esetek kivételével - nem kielégítő.

- Növelhető a szájüregi egészség, ha alkalmaznák a személyre szabott dentálhigiénét, bevezetnék a szájápolásban a szájöblítőket, a fluortartalmú fogkrémeket, segítenék a velük foglalkozó személyek képzését és motivációját.

- A kezelésben együtt kell múködni az erre szakosodott civil szervezetekkel, alapítványokkal, gyógypedagógusokkal, pszichiáterekkel, fogorvosokkal.

A fogászati ellátás szükségleteinek hazai felmérését és a prevenciós lehetőségeket, ezek eredményeit a következő cikkünkben kívánjuk ismertetni.

Anyagi támogatás: A közlemény megírása, illetve a kapcsolódó munka anyagi támogatásban nem részesült.

Szerzôi munkamegosztás: Sz. I., G. E., Szmirnov Gy.: Gyakorlati munka. P. G.T.: Irodalomkutatás, részvétel a közlemény megírásában. N. Zs.: Részvétel a közlemény megírásában. Szabó Gy.: Szakmai felügyelet. A cikk végleges változatát valamennyi szerző elolvasta és jóváhagyta.

Érdekeltségek: A szerzőknek nincsenek érdekeltségeik.

\section{Irodalom}

[1] Gruiz K. Complex dental program for mentally handicapped and crammed people. [Komplex fogorvosi program értelmileg fogyatékos és halmozottan sérült emberek számára.] Személyes közlés, 1996. [Hungarian]

[2] Persons with disabilities. [Fogyatékosságal élő személyek.] Képviselői Információs Szolgálat, Infojegyzet 2013/13. Available from: http://www.parlament.hu/documents/10181/ 59569/Infojegyzet_2013_13_fogyatekossaggal_elok.pdf/ f5e90323-1f76-455f-83ca-4ae87239349f [accessed: April 11, 2019]. [Hungarian]

[3] Hungary in the context of oral epidemiological studies, 2009 [Magyarország az orális epidemiológiai vizsgálatok tükrében, 2009.] Központi Statisztikai Hivatal, Budapest, 2009. Available from: http://semmelweis.hu/propedeutika/files/2012/12/ Magyarorsz\%C3\%Alg-az-or\%C3\%Allis-epidemiol\%C3\%B3giaivizsg\%C3\%Allatok-t\%C3\%BCkr\%C3\%A9ben-2009pdf.pdf [accessed: April 11, 2019]. [Hungarian]

[4] Ajami BA, Shabzendedar M, Rezay YA, et al. Dental treatment needs of children with disabilities. J Dent Res Dent Clin Dent Prospects 2007; 1: 93-98.

[5] Binkley CJ, Johnson KW, Abadi M, et al. Improving the oral health of residents with intellectual and developmental disabilities: an oral health strategy and pilot study. Eval Program Plann. 2014; 47: 54-63.

[6] McKelvey VA, Morgaine KC, Thomson WM. Adults with intellectual disability: a mixed-methods investigation of their experi- ences of dental treatment under general anaesthetic. N Z Dent J. 2014; 110: 58-64.

[7] Wang YC, Huang GF, Cheng YJ, et al. Analysis of clinical characteristics, dental treatment performed, and postoperative complications of 200 patients treated under general anesthesia in a special needs dental clinic in northern Taiwan. J Dent Sci. 2015; 10: 172-175.

[8] Dolce Filho R. Homeopathic approach in the treatment of patients with mental disability. Homeopathy 2006; 95: 31-44.

[9] Solanki N, Kumar A, Awasthi N, et al. Assessment of oral status in pediatric patients with special health care needs receiving dental rehabilitation procedures under general anesthesia: a retrospective analysis. J Contemp Dent Pract. 2016; 17: 476-479.

[10] Edwards DM, Merry AJ, Pealing R. Disability part 3: improving access to dental practices in Merseyside. Br Dent J. 2002; 193: 317-319.

[11] Montiel-Company JM, Almerich-Silla JM. Efficacy of two antiplaque and antigingivitis treatments in a group of young mentally retarded patients. Med Oral. 2002; 7: 136-143.

[12] Reuland-Bosma W. Dissertations 25 years after date 35. Periodontal disease in Down syndrome: an immunological disorder. Ned Tijdschr Tandheelkd. 2013; 120: 541-545. [Article in Dutch]

[13] Solanki J, Khetan J, Gupta S, et al. Oral rehabilitation and management of mentally retarded. J Clin Diagn Res. 2015; 9: ZE01ZE06.

[14] Chhajed S, Bhambhani G, Agarwal R, et al. Impact of various extra-oral factors on caries experience among mentally disabled children residing in Bhopal city, central India: a cross-sectional study. J Indian Soc Pedod Prev Dent. 2016; 34: 285-290.

[15] Ismailov AI. Prophylaxis of oral diseases in patients with disabilities. [Исмаилов АИ. Профилактика стоматологических заболеваний у лиц с умственной отсталостью.] Moscow, 2008. Available from: http://medical-diss.com/docreader $/ 553130 /$ a?\#?page $=6$ [accessed: April 11, 2019]. [Russian]

[16] Chang J, Lee JH, Son HH, et al. Caries risk profile of Korean dental patients with severe intellectual disabilities. Spec Care Dentist. 2014; 34: 201-207.

[17] Wang YC, Lin IH, Huang CH, et al. Dental anesthesia for patients with special needs. Acta Anaesthesiol Taiwan. 2012; 50: $122-125$

[18] Corcuera-Flores JR, Delgado-Muñoz JM, Ruiz-Villandiego JC, et al. Dental treatment for handicapped patients; sedation vs general anesthesia and update of dental treatment in patients with different diseases. Med Oral Patol Oral Cir Bucal 2014; 19: el70-el76.

[19] Maeda S, Tomoyasu Y, Higuchi H, et al. Midazolam is associated with delay in recovery and agitation after ambulatory general anesthesia for dental treatment in patients with disabilities: a retrospective cohort study. J Oral Maxillofac Surg. 2012; 70: 13151320 .

[20] Sitkin SI, Gasparian AL, Ivanova TI, et al. Long-term dental interventions in mentally retarded children under general anesthesia with sevoflurane. Stomatologiia (Mosk). 2015; 94: 59-60. [Russian]

[21] Károlyházy K, Schmidt P, Bogdán S, et al. Prosthodontic treatment of an edentulous epileptic patient with an implant-retained overdenture. A case report. [Fogatlan epilepsziás betegek kezelése implantátumrögzítésú fogpótlással.] Ideggyógy Szle. 2014; 67: 342-346. [Hungarian]

[22] Szántó I, Sándor B. Preventive health care of patients with special needs. [Speciális ellátási körülményeket igénylő páciensek preventív kezelése.] Magy Fog. 2014; 23: 256-258. [Hungarian]

[23] Bücher K, Kühnisch J, Hickel R, et al. Focal points for treating patients with disabilities and chronic illness. [Fogyatékos és krónikus betegségben szenvedő páciensek kezelésének súlypontjai.] Quintessenz Int. 2018; 3: 51-61. [Hungarian] 
[24] Tanboga I, Durhan MA, Durmus B, et al. Temporomandibular disorders in young people with an intellectual disability: prevalence of signs and symptoms. Eur J Paediatr Dent. 2014; 15: 349-354.

[25] Abeleira MT, Outumuro M, Ramos I, et al. Dimensions of central incisors, canines, and first molars in subjects with Down syndrome measured on cone-beam computed tomographs. Am J Orthod Dentofacial Orthop. 2014; 146: 765-775.

[26] McKinney CM, Nelson T, Scott JM, et al. Predictors of unmet dental need in children with autism spectrum disorder: results from a national sample. Acad Pediatr. 2014; 14: 624-631.

[27] Naouri D, Bussiere C, Pelletier-Fleury N. What are the determinants of dental care expenditures in institutions for adults with disabilities? Findings from a national survey. Arch Phys Med Rehabil. 2018; 99: 1471-1478.
[28] Mac Giolla Phadraig C, Nunn J, Dougall A, et al. What should dental services for people with disabilities be like? Results of an Irish Delphi panel survey. PLoS ONE 2014; 9: ell3393.

[29] Waldman HB, Perlman SP, Swerdloff M. Children with mental retardation/developmental disabilities: do physicians ever consider needed dental care? Ment Retard. 2001; 39: 53-56.

[30] Viana GR, Teiltelbaum AP, dos Santos FA, et al. Chlorhexidine spray as an adjunct in the control of dental biofilm in children with special needs. Spec Care Dentist. 2014; 34: 286-290.

(Szabó György dr., Budapest, Mária u. 52., 1085 e-mail: szabogy@dent.semmelweis-univ.hu)

\section{"Audentes fortuna juvat." (Vergilius) \\ (Bátraké a szerencse.)}

A cikk a Creative Commons Attribution 4.0 International License (https://creativecommons.org/licenses/by/4.0/) feltételei szerint publikált Open Access közlemény melynek szellemében a cikk bármilyen médiumban szabadon felhasználható, megosztható és újraközölhetö, feltéve, hogy az eredeti szerző és a közlés helye, illetve a CC License linkje és az esetlegesen végrehajtott módositások feltüntetésre kerülnek. (SID_1) 